\title{
Organic richness and gas generation potential of Permian Barren Measures from Raniganj field, West Bengal, India
}

\author{
Annapurna Boruah* and S Ganapathi \\ Department of Geology, The Maharaja Sayajirao University of Baroda, Vadodara 390 002, India. \\ ${ }^{*}$ Corresponding author. e-mail: annapurna_1910@yahoo.in
}

The organic geochemistry of shales in terms of its organic richness, hydrocarbon source potential, thermal maturity, depositional environment, etc., are essential stipulations for shale gas resources assessment. In this study, a total of 32 core samples of Permian Barren Measures from four boreholes in Raniganj field of Damodar Basin were analysed to evaluate their gas generation potential using Rock-Eval pyrolysis techniques. Petrographic analysis brings out the lithofacies of Barren Measures as carbonaceous silty shale, iron rich claystone and sand-shale intercalation. The total organic content (TOC) of the shale units of Barren Measures ranges from 3.75 to $20.9 \mathrm{wt} \%$, whereas hydrogen index (HI) ranges from 58.45 to $125.34 \mathrm{mg} \mathrm{HC} / \mathrm{g}$ TOC. Present study suggests early to late maturated (0.6-1\%) organic matters in Barren Measures with gas prone type III kerogen. The study analysed the effect of burial history on the preservation and maturation of organic matters. The organic richness, kerogen type, thermal maturity and petrographic properties of Barren Measures signify fair to excellent gas generation potential.

\section{Introduction}

The current boom in the exploration and development of shale gas resources in USA (Curtis 2002; Montgomery et al. 2005; Jarvie et al. 2007; Ross and Bustin 2007) has created interest in the assessment of shale gas resource potential of India. The total organic content, thermal maturity, absorbed gas fraction, volume of gas in place, mineralogy etc., are the important parameters of shale gas generation and retention (Curtis 2002; Law and Curtis 2002; Jarvie et al. 2007). Whether the shale formation can produce oil or gas, depends on a number of factors like (i) quality and quantity of organic matter, (ii) type of kerogen, (iii) duration and scale of heating (Boyer et al. 2006), etc. Unlike the conventional petroleum reservoir systems, shale reservoirs are continuous (Jarvie et al. 2007 ), have low porosity $(<10 \%)$, and are ultra permeable $(<1 \mathrm{Md})$ with a wide range of compositional variation (Herge et al. 2004; Loucks et al. 2009; Kuila and Prasad 2013). The shale rock with more than $2 \%$ total organic content (TOC) often has significant source potential. When TOC is between 1 and $2 \%$, depositional environment intermediates between oxidizing and reducing, if TOC is above $2 \%$, it indicates reducing environment with excellent hydrocarbon source potential (Demaison and Moore 1980; Bissada 1982; Peters 1986; Leckie and Kalkreuth 1988; Bacon et al. 2000; Dembicki 2009). The amount and type of organic matters preserved in the sediments are not only controlled by the depositional environment but also by the productivity of the water, physical conditions in the area of deposition and mineral constituents of the sediments (Barker 1974; Banerjee et al. 1998; Bacon et al. 2000). The shale with high quartz, feldspar and carbonate content have low Poisson's ratio and high Young's modulus points towards high brittleness, thus results in development of fracture in

Keywords. Barren Measures; Raniganj; Rock-Eval pyrolysis; shale gas; TOC.

J. Earth Syst. Sci. 124, No. 5, July 2015, pp. 1063-1074

(C) Indian Academy of Sciences 
the shale, under external forces (Potter et al. 1980; Law and Curtis 2002). Fractures provide migration conduits and accumulation spaces for natural gas and formation water (Curtis 2002). Advanced exploration technologies have been used in USA for commercial shale gas production from different shale plays such as Barnett, Antrim, New Albany, Marcellus, Ohio, Haynesville, Fayetteville, Woodford, etc. (Law and Curtis 2002; Bowker 2003; Brown 2006). India with its enormous prospect of unconventional shale gas resources can effectively make the global natural gas curve more elastic. Oil and Natural Gas Corporation Ltd. of India, drilled Asia's first (shale gas pilot project) shale gas well (RNSG-1 and RNSG-2) at Icchapur village near Durgapur in West Bengal, the eastern part of Raniganj field of the Damodar Valley (LNG report 2011). The Permian shales of this field are the prospective shale gas plays of India (ONGC report 2010; Varma et al. 2014). Coal resources are being explored from Raniganj and Barakar formations since 17th century except the Barren Measures Formation, which is devoid of coal. The Barren Measures Formation has a thick sequence of shale with high organic matter content and potential reservoir for shale gas (Mishra 2009; ONGC report 2010; Varma et al. 2014). This paper presents the organic richness, thermal maturity and gas generation potential of Barren Measures shale of Raniganj field. An attempt has also been made to understand the key geological factors and processes in order to identify prospective shale gas fairway over Raniganj field.

\section{Geological settings}

The Gondwana basins in India are intra-cratonic in nature, surrounded by Pre-Cambrian terrains, correspondingly occur as separate outliers along the three major directions: (1) Son-Narmada and Damodar-Koel Valley, running east-west, (2) SonMahanadi Valley, with a NW-SE trend, and (3) Pranhita-Godavari Valley, which trends in a NNW-SSE direction. The Gondwana successions of Damodar Basin in peninsular India accumulated in a number of discrete sub-basins during the Permo-Triassic period. The belt of Gondwana basins lies within the Chotanagpur Granite Gneiss belt and the main sub-basins are Hutar, Auranga, Karanpura, Bokaro, Jharia and Raniganj (Chakraborty et al. 2003). They have faunal and floral characteristics similar to the equivalent strata of South America, South Africa, Australia and Antarctica (Veevers and Tewari 1995). Raniganj field (figure 1a) is the easternmost depository within the Damodar Basin, a typical halfgrabben type $\mathrm{E}-\mathrm{W}$ trending and westerly plunging synform. Depositional environment of the field is mainly terrestrial (fluvial and lacustrine) with local marine transgressions during the SakmarianArtinskian period (Ghosh 2002; Chakraborty et al. 2003). The lithostratigraphy (table 1) of the field is represented by glaciogenic Talchir Formation of early Permian age at the base, overlying the Pre-Cambrian metamorphic rocks unconformably. The coal bearing Barakar and Raniganj formations are overlaying the Talchir deposits. The Barakar Formation is characterized by conglomerate, light grey to light yellowish/brownish, gritty to pebbly, arkosic to sub-arkosic, cross-bedded sandstone and siltstone, interbedded with grey/black shale and coal (Fox 1993; Casshyap and Tewari 1988; Gupta 1999). The Barren Measures Formation is sandwiched between Barakar and Raniganj formations, fluvial-lacustrine origin and devoid of coal (Dasgupta 2005; Murthy et al. 2010). Presence of trace fossils (Skolithos, Cruziana, Thalssinoid), palynomorh assemblages, high salinity, wave and storm sedimentary structure, marine trace elements (boron, vanadium, chromium), etc., suggest the marine influence invasion (continental to epeiric shallow sea) in Upper Barakar and Barren Measures formations (Gupta 1999; Ghosh 2002). The alluvial deposit of the Panchet Formation is also barren of coal and it overlies the Raniganj Formation. The Barren Measures of Permian age is recognized as the shale gas prospective horizon based on thickness $(>1000 \mathrm{~m})$, areal extent and higher content $(>2 \%)$ of organic matter (ONGC 2010; Varma et al. 2014, 2015). This paper is to assess the organic richness, kerogen type, gas generation potential and thermal maturity of Barren Measures belonging to $\mathrm{N}-\mathrm{W}$ part of Raniganj field in Burdwan district of West Bengal, located between latitudes $23^{\circ} 46^{\prime} 00^{\prime \prime}-23^{\circ} 43^{\prime} 00^{\prime \prime} \mathrm{N}$ and longitudes $86^{\circ} 52^{\prime} 00^{\prime \prime}-86^{\circ} 55^{\prime} 30^{\prime \prime} \mathrm{E}$. The study area (figure 1b) extends from Chalbalpur village in the west to Mahismura village in the east, which is marked by the Barakar Barren Measures contact, while the southern limit is marked by the Raniganj Barren Measures contact (Das 1992). Thickness of Barren Measures Formation ranges from 91 to $330 \mathrm{~m}$ in the study area. However, thickness is more $(750-850 \mathrm{~m})$ towards the southern margin as compared to the northern margin and best developed $(>1000 \mathrm{~m})$ in the depressions (Durgapur and Raniganj Depressions) of Raniganj field (ONGC 2010). Yet, the shale necessitates exhaustive investigations to understand its gas generation potential.

\section{Sampling and analytical techniques}

The continuous core samples of Barren Measures Formation was studied and litho-units were identified from four boreholes, i.e., B\#1, B\#2, B\#3 and $\mathrm{B} \# 4$. The thin sections of selective samples 
$(n=50)$ were analysed using standard petrographic techniques (Thiessen et al. 1938; Kennedy and George 1945; Fowler and Shirley 1947; Greensmith 1988) with the help of polarizing microscope (maximum resolution 40X) to envisage their petrographic characters such as mineral constituent, porosity, textures, fabrics, diagenesis, etc.
(Potter et al. 1980; Adams et al. 1984; Pettijohn 1984; Adams and Mackenzie 1998).

The TOC was determined by using LECO EC12 carbon analyser (Lafargue et al. 1998). Approximately $0.2 \mathrm{~g}$ of the sample was weighed, treated with concentrated hydrochloric acid to remove carbonates, and vacuum filtered on glass fiber paper.
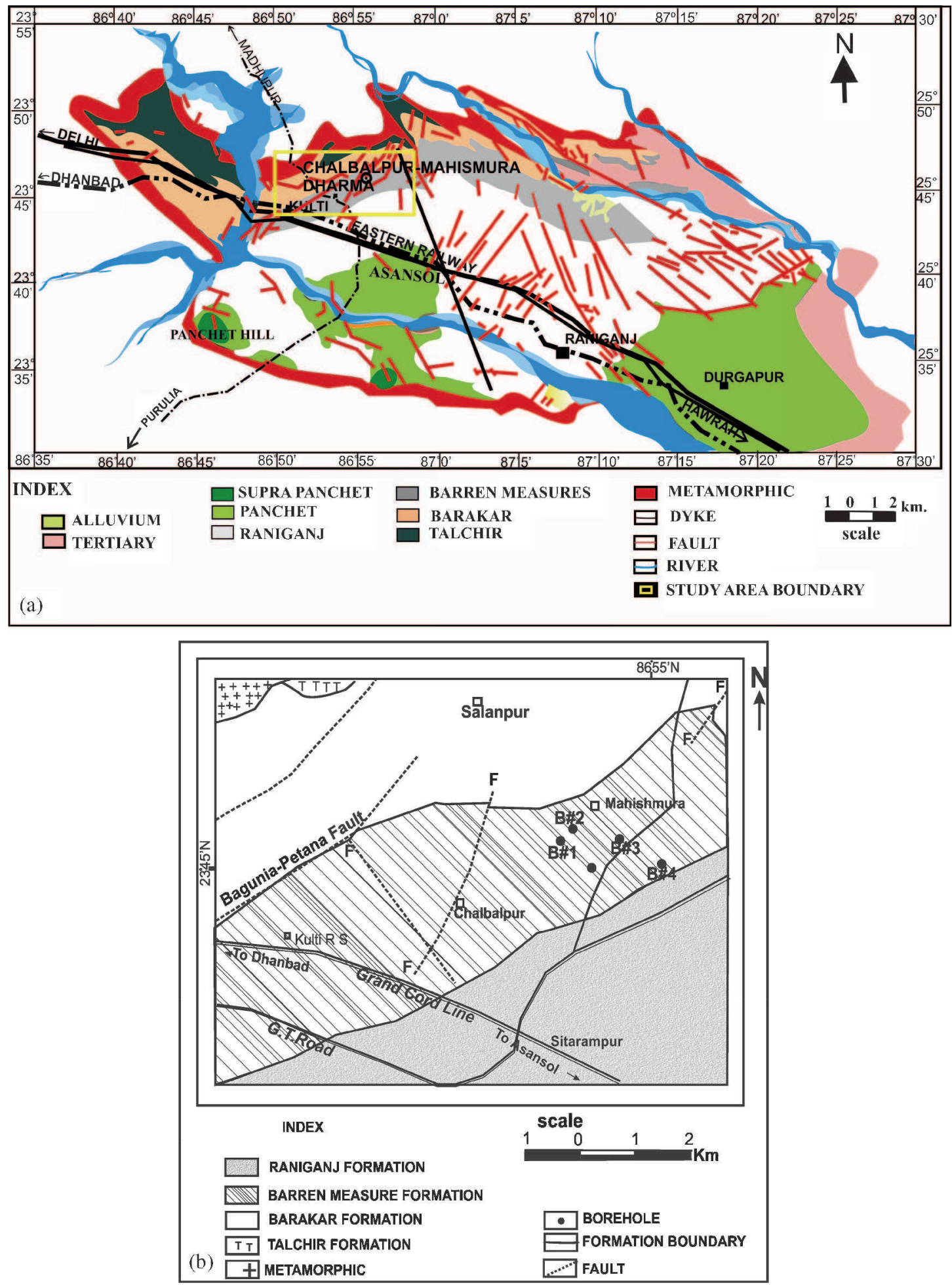

Figure 1. (a) Geology map of Raniganj field (Das 1992; CMPDIL 1993). (b) Study area map with borehole locations. 
Table 1. General stratigraphy of Raniganj field (Ghosh 2002).

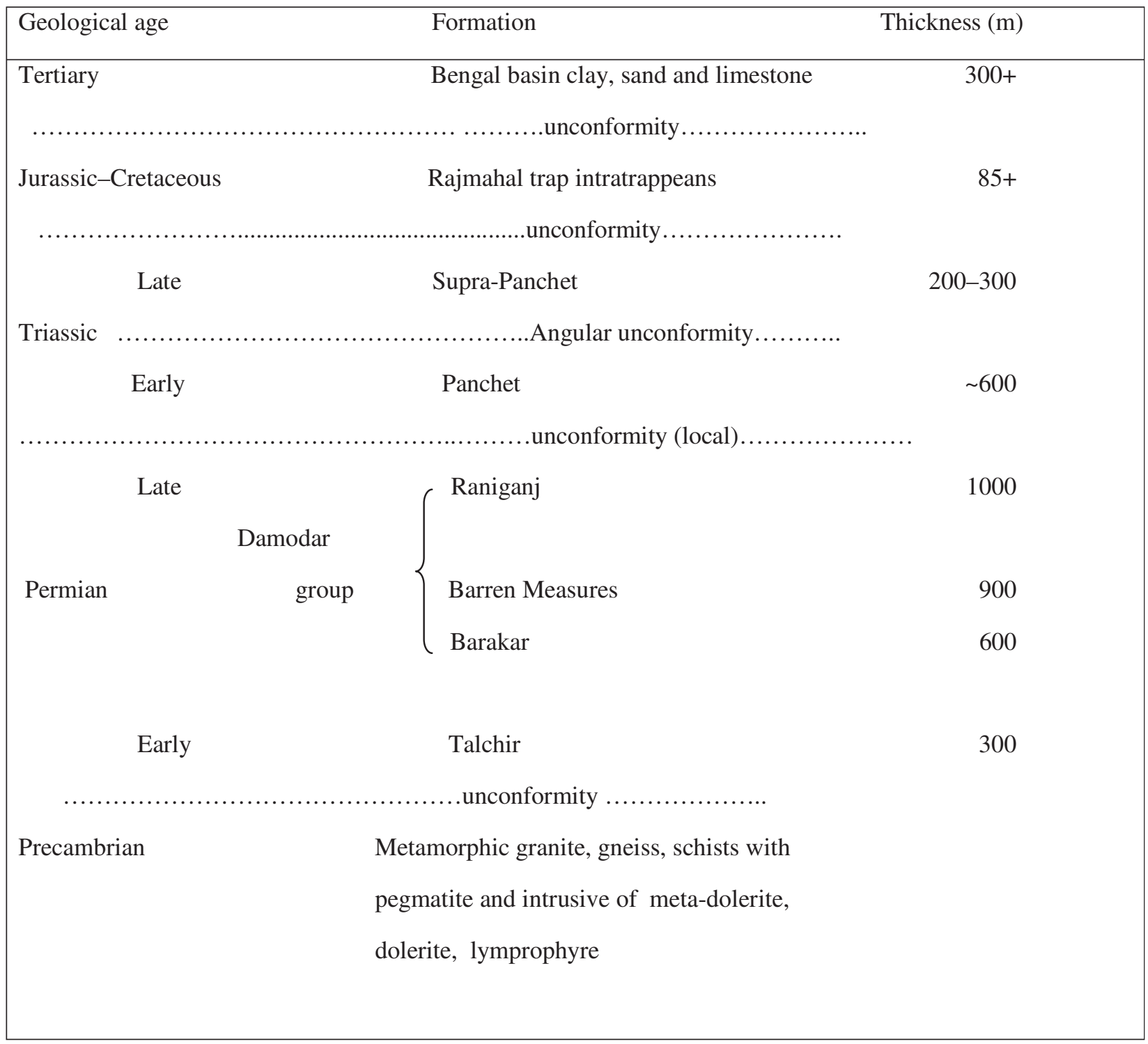

The LECO EC-12 system is a microprocessor based instrument for determining carbon content in coal, coke, petroleum products, shale, ores and many other nonmetallic materials. EC-12 is used to combust the samples in an oxygen atmosphere at about $1000^{\circ} \mathrm{C}$ where the carbon oxidizes to carbon dioxide. Moisture and dust were removed and $\mathrm{CO}_{2}$ gas was measured by solid state infrared detector (Kniesa and Mannb 2002; Stein 2007; Farhaduzzaman et al. 2012; Mani et al. 2014).

Rock-Eval pyrolysis technique has been used to determine the petroleum potential and the thermal maturity of the kerogen occurring in a rock (Barker 1974; Espitalie 1986; Banerjee et al. 2006; Jarvie et al. 2007). Details of the analytical methods have been described by Tissot and Welte (1984), Espitalie (1986) and Peters (1986). Here, the hydrocarbon generation potential of Barren Measures shale samples $(n=34)$ was assessed using the Rock-Eval 6 pyrolyser (Turbo version - Vinci Technologies). The complete process was carried out in two ovens, i.e., pyrolysis and oxidation (combustion) of Rock-Eval pyrolyser. Pyrolysis continues with an isothermal temperature program of $300^{\circ}-650^{\circ} \mathrm{C}$ in an inert atmosphere of nitrogen with a rise of $25^{\circ} \mathrm{C}$ per minute. The pyrolyzed hydrocarbons were controlled by a flame ionization detector (FID). Pyrolysis analysis provides four vital parameters: (1) thermo-vapourized free hydrocarbons (S1 peaks); (2) pyrolysis hydrocarbon from cracking of organic matter (S2 peaks), the amount of hydrocarbon not yet released from the rock by natural processes. It represents the residual petroleum potential; (3) the amount of $\mathrm{CO}_{2}$ released through heating organic matter (S3 peaks); and (4) the highest temperature for generating a maximum amount of hydrocarbon during pyrolysis $\left(T_{\max }\right)$. The $T_{\max }$ value is a maturity parameter and corresponds to the temperature 
at which maximum amount of hydrocarbons are released from the thermal degradation of kerogen, i.e., S2 peak. It is used as an indicator of the thermal maturity of rock (Espitalie 1986). The calculated parameters of Rock-Eval, i.e., the hydrocarbon potential or hydrogen index (HI) is defined by $100 \times \mathrm{S} 2 / \mathrm{TOC}$. The oxygen index (OI) is defined as $100 \times \mathrm{S} 3 / \mathrm{TOC}$, where $\mathrm{S} 3$ is the $\mathrm{CO}_{2}$ released during the pyrolysis. Both the measured and calculated parameters from Rock-Eval pyrolysis, help in determination of kerogen type, hydrocarbon generation efficiency and maturation. The hydrocarbon generation and maturation processes are highly controlled by time, temperature, pressure, depth of burial, etc. (Peters 1986; Hunt John 1995; Jarvie et al. 2007). Therefore, the experimental temperatures were set comparatively higher than normal subsurface conditions, so that appreciable reaction for the generation of hydrocarbons can occur in a reasonably short time and amount of generated hydrocarbons relative to the total potential of the source rock can be estimated (Barker 1977; Peters 1986; Espitalie 1986; Nuñez Betelu and Baceta 1994; Banerjee et al. 2006; Mani et al. 2014).

\section{Result and discussion}

\subsection{Barren Measures litho-units}

The characteristics of litho-units such as texture, colour, stratification, structure, components, and grain-size distribution, etc., are important in understanding the depositional environment, organic richness and reservoir properties (Pettijohn 1984; Wang Guochang 2013). The geology, stratigraphy, depositional environment, etc., of Raniganj field have been widely documented in previous literatures (Fox 1931; Casshyap and Tewari 1988; Chakraborty et al. 2003); however, the lithofacies variation, mineral composition, diagenesis processes, etc., in relation to hydrocarbon generation and retention of Barren Measures require detailed investigation. The megascopic borehole cores analysis indicates that Barren Measures overlies the Barakar Formation with gradational contact and the contact is represented by the intercalation of thin sand and shale layers. The Barren Measures comprises medium-to-fine grain sandstone, black carbonaceous shale, sandy shale, siltstone, ironstone band, intercalation of sandstone and shale at the base. The shale unit is grey to dark black in colour, laminated to blocky, fissile to hard massive with silt size mica grains in large quantity (almost $5-10 \%)$. It is tight, compacted and pores are rarely visible, and compositionally carbonaceous and siliceous in nature. Fine-to-medium grain sandstones are present as thin lamiae or sometimes as small irregular patches and ferruginous lamina. Quartz, lithic fragment and iron rich, carbonaceous, argillaceous matrix was clearly seen in microscopic images (figure $2 \mathrm{a}-\mathrm{f}$ ). Presence of moderate to well-sorted, sub-rounded to wellrounded grains indicates the good maturity of sediment and long distance transport. The shale contains less than one-third clay minerals with abundant quartz and feldspar silt. Organic materials are present in the form of flakes or sub-rounded particles and scattered over the rock matrix (figure 2b). The diagenetically altered microcrystalline silica is present as a major component of the siliceous shale unit. The sequence is repetitive finning upward and contains thin lines of siderite and fragments of pyrite. Under microscope, the rocks reveal alternate silt and clay laminations (figure 2a, e, f) whereas organic matter flakes are abundant in the black carbonaceous shales (Pettijohn 2004; Wang 2013). Occurrence of pyrite mineral (figure 2c) indicates the anoxic condition of sediment deposition (Schieber 1996; Schieber and Baird 2001). Anoxic conditions in Raniganj field may be a result of stagnation conditions, density stratification in lake, inputs of organic material which lead to preservation of carbon and carbon compounds. The pyrite may be precipitated from the iron dominated pore waters at the site of sulphur supply where organic matter may be deposited due to bacterial sulfate reduction. The assemblage of quartz + sericite + pyrite, refers phyllic alteration at high temperatures and moderately acidic (low $\mathrm{pH}$ ) conditions (Pettijohn 1984; Parry et al. 2002). The compaction effect is evidenced by point, straight and concavo-convex contacts (figure 2e) of framework grains. Compaction has resulted in a reduction of the original size of pore bodies and pore throats, and therefore has contributed to a general reduction in porosity and permeability during burial while floating grain contact is seen (figure 2b) in most of the studied samples which indicates the possibility of intergranular pores (Pettijohn 1984).

\subsection{Total organic content (TOC)}

The dark grey to black colour of the studied shale samples from Barren Measures indicates high content of organic matter (Potter et al. 1980; Pettijohn 1984; Varma et al. 2014). The laboratory measured TOC value ranges from 3.75-20.9 wt\% (table $2 \mathrm{a}-$ d). The highest TOC content is observed at the depth interval 155-160 $\mathrm{m}$ in borehole B\#1. Generally, the variation in TOC content is caused by climatic variations of sediment deposition, decomposition, weathering effect and/or thermal maturation with burial, etc. (Jenny 1941; Schlesinger 1977; Potter et al. 1980; Hunt John 1995; Stein 2007; Wang 2013). Oxygen depleted or anoxic, low energy environment is the best medium 

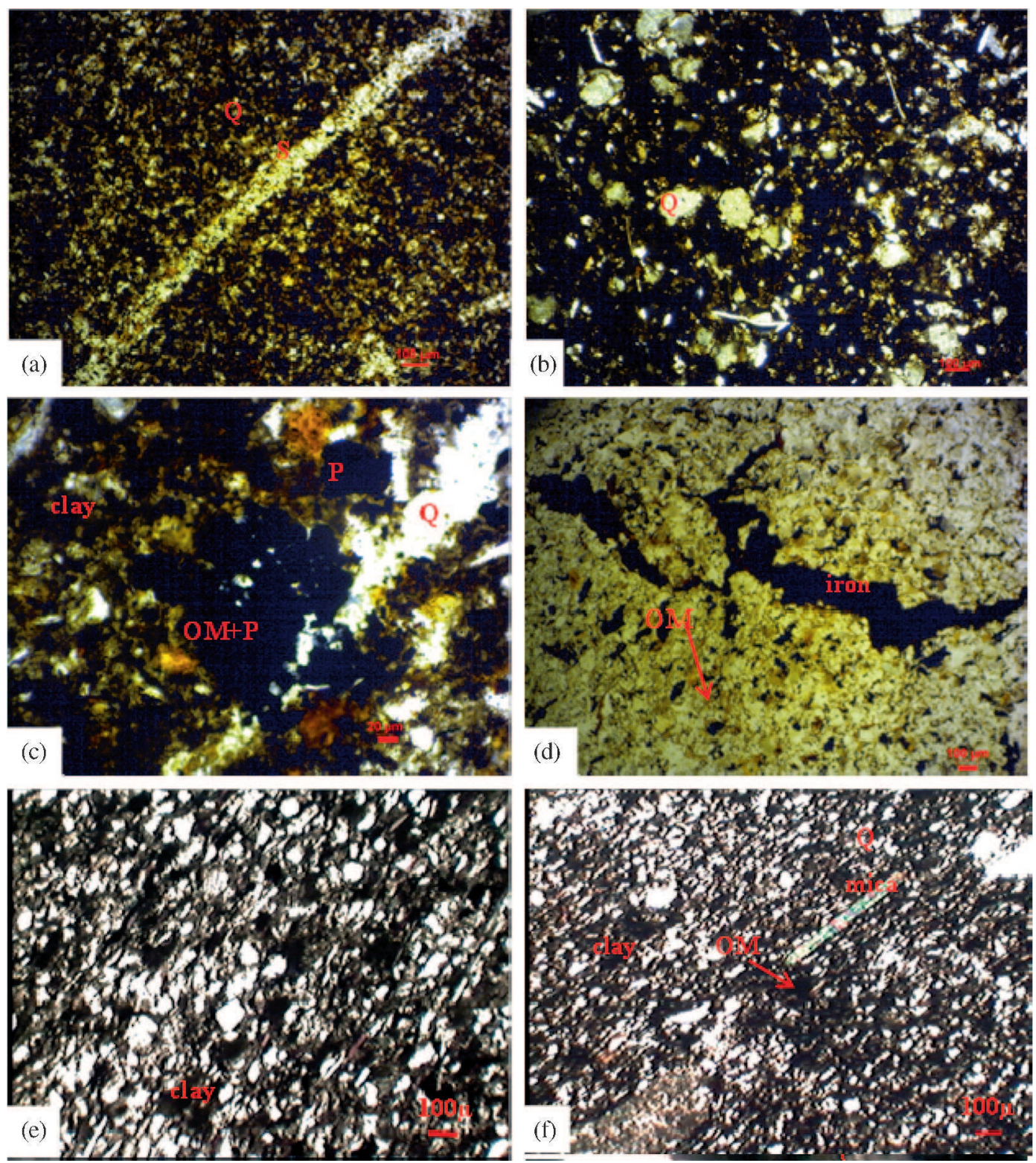

Figure 2. Photomicrographs of Barren Measures shales (OM=organic matter, $\mathrm{P}=$ pyrite, $\mathrm{Q}=$ quartz, $\mathrm{S}=$ sericite). (a) A fracture filling silt lamina is present with partially altered sericite, argillaceous matrix, well-sorted and rounded fine grains, quartz dominant. The rock type is ironstone shale (depth $157 \mathrm{~m}, \mathrm{~B} \# 3 ;$ 4X). (b) Quartz, muscovite and chlorite minerals are common. Moderated to well sorted silt grains with random orientation (depth 125 m, B\#3; 10X). (c) Organic matters coated with iron. A few quartz layers and iron oxides are dominant with authigenic pyrite. The rock type is carbonaceous

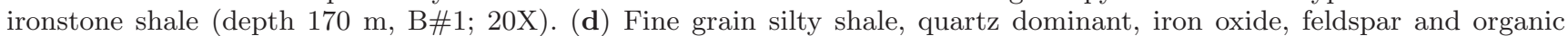
matters are present. The rock type is ferruginous siltstone (depth 105 m, B\#2; 4X). (e) Silt and mica grains are aligning parallel in preferred direction with their long axes parallel to flow, grains are in concavo-convex and point contact (4X). (f) Sub-angular to subrounded quartz, muscovite grains, floating to point contact, organic matters are filling intergranular pore spaces. The rock type is micaceous laminated shale (depth 145-150 m, B\#1; 4X).

for preserving organic matter (Demaison and Moore 1980). The considerably low measured TOC for samples belonging to borehole B\#4 indicates the vertical TOC variation with depth of burial. Post-depositional diagenesis processes, increasing pressure and temperature with burial depth, etc., cause thermal alteration of organic matter which may lead to TOC variation, i.e., TOC loss with depth is due to maturation, hydrocarbon generation and expulsion. Previous studies strongly suggested that such differences are due to conversion of organic matter to hydrocarbons in the subsurface (Montgomery et al. 2005; Jarvie et al. 2007). In this study, the original TOC $\left(\mathrm{TOC}_{\mathrm{O}}\right)$ differs from the present day TOC $\left(\mathrm{TOC}_{\mathrm{P}}\right)$ content $\left(\mathrm{TOC}_{\mathrm{P}} / 0.64=\mathrm{TOC}_{\mathrm{O}}\right)$ and it is higher than present day TOC (Jarvie and Lundell 1991; Javier 2004). The calculated original TOC ranges from 5.85-32.65 wt\% for studied shale samples. 


\begin{tabular}{|c|c|c|c|c|c|c|c|c|}
\hline $\begin{array}{l}\text { Depth } \\
\text { intervals (m) }\end{array}$ & $\begin{array}{c}\mathrm{S} 1 \\
(\mathrm{mg} \mathrm{HC} / \mathrm{g} \text { rock })\end{array}$ & $\begin{array}{c}\mathrm{S} 2 \\
(\mathrm{mg} \mathrm{HC} / \mathrm{g} \text { rock })\end{array}$ & $\begin{array}{c}\mathrm{S} 3 \\
(\mathrm{mg} \mathrm{CO} / \mathrm{g} \text { rock })\end{array}$ & $\begin{array}{l}\text { TOC } \\
(\mathrm{wt} \%)\end{array}$ & $\begin{array}{l}T_{\max } \\
\left({ }^{\circ} \mathrm{C}\right)\end{array}$ & PI & $\begin{array}{c}\mathrm{HI} \\
(\mathrm{mg} \mathrm{HC} / \mathrm{g} \text { TOC})\end{array}$ & $\begin{array}{c}\mathrm{OI} \\
(\mathrm{mg} \mathrm{CO} / \mathrm{g} \text { TOC })\end{array}$ \\
\hline \multicolumn{9}{|l|}{ B\#1 } \\
\hline $150-155$ & 1.2 & 10.59 & 0.2 & 12.98 & 445 & 0.101 & 81.587 & 1.540 \\
\hline $155-160$ & 1.91 & 14.99 & 0.56 & 20.9 & 445 & 0.113 & 71.722 & 2.679 \\
\hline $170-175$ & 0.98 & 8.9 & 0.56 & 12 & 446 & 0.099 & 74.166 & 4.666 \\
\hline $175-180$ & 0.94 & 6.98 & 0.34 & 11.56 & 446 & 0.118 & 60.380 & 2.941 \\
\hline $180-185$ & 0.92 & 6.3 & 0.41 & 6.78 & 447 & 0.127 & 92.920 & 6.047 \\
\hline 185-190 & 1.94 & 5.98 & 0.45 & 8.37 & 447 & 0.244 & 71.445 & 5.376 \\
\hline 190-195 & 0.71 & 3.56 & 0.33 & 6.09 & 448 & 0.166 & 58.456 & 5.418 \\
\hline $195-200$ & 0.33 & 2.57 & 0.85 & 3.75 & 448 & 0.113 & 68.533 & 22.666 \\
\hline \multicolumn{9}{|l|}{ B\#2 } \\
\hline $91-95$ & 0.8 & 4.12 & 0.42 & 4.74 & 433 & 0.162 & 86.919 & 8.860 \\
\hline $96-100$ & 0.74 & 6.03 & 0.5 & 6.67 & 435 & 0.109 & 90.404 & 7.496 \\
\hline $100-105$ & 0.95 & 9.89 & 0.4 & 7.89 & 437 & 0.087 & 125.348 & 5.069 \\
\hline $105-120$ & 0.88 & 5.45 & 0.3 & 6.78 & 439 & 0.139 & 80.383 & 4.424 \\
\hline $110-115$ & 0.98 & 8.41 & 0.52 & 10.69 & 441 & 0.104 & 78.671 & 4.864 \\
\hline $115-120$ & 0.73 & 6.31 & 1.45 & 9.94 & 443 & 0.103 & 63.480 & 14.587 \\
\hline $120-125$ & 1.94 & 17.05 & 0.29 & 17.88 & 443 & 0.102 & 95.357 & 1.621 \\
\hline $125-130$ & 1.66 & 14.2 & 0.3 & 19.98 & 444 & 0.104 & 71.071 & 1.501 \\
\hline $130-135$ & 1.94 & 12.23 & 0.6 & 17.88 & 444 & 0.136 & 68.400 & 3.355 \\
\hline $135-140$ & 1.19 & 10.34 & 0.8 & 12 & 445 & 0.103 & 86.166 & 6.666 \\
\hline $150-155$ & 1.03 & 12.59 & 0.8 & 13.69 & 445 & 0.075 & 91.964 & 5.843 \\
\hline $155-160$ & 1.84 & 18.49 & 0.57 & 20.88 & 445 & 0.090 & 88.553 & 2.729 \\
\hline $185-190$ & 1.44 & 6.68 & 0.42 & 9.73 & 446 & 0.177 & 68.653 & 4.316 \\
\hline 190-195 & 0.81 & 4.83 & 0.33 & 4.97 & 447 & 0.143 & 97.183 & 6.639 \\
\hline \multicolumn{9}{|l|}{ B\#3 } \\
\hline $110-115$ & 1.8 & 12.23 & 0.42 & 12.85 & 441 & 0.128 & 95.175 & 3.268 \\
\hline $115-120$ & 1.39 & 9.85 & 1.02 & 11.26 & 442 & 0.123 & 87.477 & 9.058 \\
\hline $120-125$ & 1.19 & 12.06 & 0.83 & 13.08 & 443 & 0.089 & 92.201 & 6.345 \\
\hline $150-154$ & 0.67 & 7.6 & 0.79 & 8.56 & 443 & 0.081 & 88.785 & 9.228 \\
\hline $157-160$ & 0.52 & 8.02 & 0.43 & 9.65 & 444 & 0.060 & 83.108 & 4.455 \\
\hline $160-162$ & 1.88 & 8.75 & 1.85 & 11.48 & 446 & 0.176 & 76.219 & 16.114 \\
\hline \multicolumn{9}{|l|}{$\mathrm{B} \# 4$} \\
\hline $301-305$ & 0.4 & 3.12 & 0.61 & 5.13 & 456 & 0.113 & 60.818 & 11.890 \\
\hline $305-310$ & 0.94 & 4.08 & 0.68 & 5.2 & 456 & 0.187 & 78.461 & 13.076 \\
\hline $310-315$ & 0.41 & 3.06 & 0.74 & 4.81 & 457 & 0.118 & 63.617 & 15.384 \\
\hline $320-321$ & 0.55 & 4.64 & 0.58 & 5.77 & 458 & 0.105 & 80.415 & 10.051 \\
\hline
\end{tabular}




\subsection{Kerogen type and hydrocarbon generation potential}

The Rock-Eval pyrolysis generated parameters are $\mathrm{S} 1, \mathrm{~S} 2, \mathrm{~S} 3$ and $T_{\max }$, whereas calculated parameters are hydrogen index (HI), oxygen index (OI), production index (PI), genetic potential (PI), maturity, etc. The important parameters obtained from the pyrolysis of shales using Rock-Eval 6 are furnished in table $2(\mathrm{a}-\mathrm{d})$. The production index or productivity index (PI) is derived from the relationship S1/(S1+S2). The PI of studied samples shows a range of $0.06-0.24 \mathrm{mg} \mathrm{HC} / \mathrm{g}$ TOC and indicates in situ petroleum generation (Peters and Moldowan 1993) of matured sediments (Peters 1986). The highest PI is observed at the depth interval of $185-190 \mathrm{~m}(\mathrm{~B} \# 1)$. The weathering processes or oxidation removes hydrogen and adds oxygen to the kerogen which can slightly alter the original PI value. Generally, the commercial gas shale producing horizons show PI values range from 0.6 to 1.5 , where shales with greater than 0.1 PI can generate excellent quantity of hydrocarbon (Ross and Bustin 2007). Organic richness or genetic potential is mathematically $(\mathrm{S} 1+\mathrm{S} 2)$ measured in $\mathrm{mg} / \mathrm{g}$ of rock (Tissot and Welte 1984). Genetic potential value and comparable source rock evaluations are shown in figure 3, where excellent genetic potential is observed in most of the studied samples. The average genetic potential (GP) is 9.54 mg $\mathrm{HC} / \mathrm{g}$ rock which ranges from 2.9 to 20.33 $\mathrm{mg} \mathrm{HC} / \mathrm{g}$ rock for the studied samples. The maximum genetic potential of $20.33 \mathrm{mg} \mathrm{HC} / \mathrm{g}$ rock was observed at the depth interval of $155-160 \mathrm{~m}$ of borehole $\mathrm{B} \# 2$. It is observed that the samples of Barren Measures shale have the HI ranging from 58.45 to $125.34 \mathrm{mg} \mathrm{HC} / \mathrm{g}$ TOC with an average HI of $80.56 \mathrm{mg} \mathrm{HC} / \mathrm{g}$ rock. Low HI $(<125.34 \mathrm{mg}$ $\mathrm{HC} / \mathrm{g}$ TOC) indicates a greater potential to generate gaseous hydrocarbon (Boyer et al. 2006). The original S2 and original HI were determined using

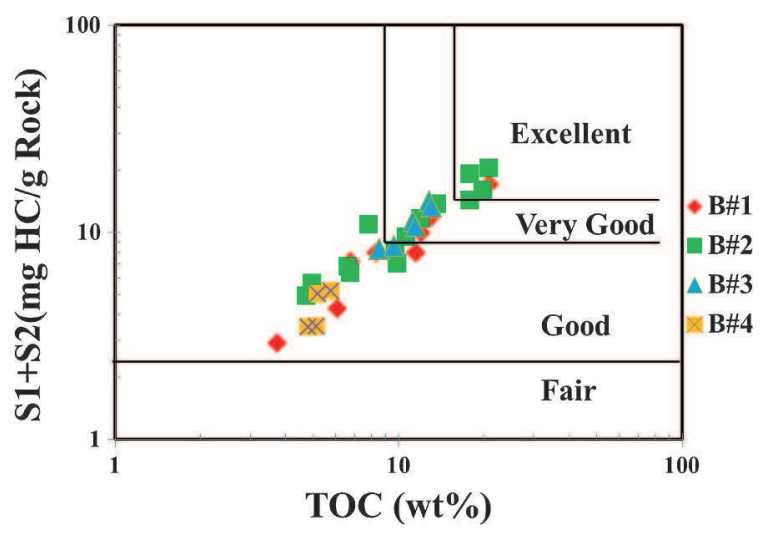

Figure 3. Cross-plots of generation potential (GP) vs. TOC, indicating good to excellent potential of Barren Measures shale (after Akinlua et al. 2005). the mathematical equations (Peter 1985; Espitalie 1986; Jarvie et al. 2004, 2007). The original generation potential (original S2 mg hydrocarbons/g rock) of studied sample is calculated numerically, i.e., original $\mathrm{S} 2=\mathrm{TOC}$ change $/ 0.083+$ present $\mathrm{S} 2$. The original S2 value ranges from 5.11 to 32.6 $\mathrm{mg} \mathrm{HC/g}$ rock. Thus original HI value is calculated using the equation Original $\mathrm{HI}=$ Original S2/Original TOC $\times 100$ (Jarvie 2004; Jarvie et al. 2007). The studied samples show original $\mathrm{HI}$ value of $80.78-138 \mathrm{mg} \mathrm{HC} / \mathrm{g}$ TOC. OI value ranges from 1.50 to $22.66 \mathrm{mg} \mathrm{CO}_{2} / \mathrm{g}$ TOC with an average of $7.13 \mathrm{mg} \mathrm{CO}_{2} / \mathrm{g}$ TOC. The crossplot between HI and OI of samples (figure 4) denotes the presence of type III, gas prone kerogen (Van Krevelen 1961; Hunt John 1995). OI trends to decrease while PI increases with burial depth (Espitalie 1986). In the present study, slight increase in the trend of PI was noticed. HI vs. $T_{\max }$ cross-plot was analysed for kerogen type determination (Hunt John 1995) and presence of type III kerogen was identified (figure 5). The plot of TOC vs. S2 visualizes (figure 6) gas prone organic matter, capable in producing mainly gas which is derived from humic and continental higher plants (Tissot 1984; Tissot and Welte 1984; Alias 2012; Slatt and Rodriguez 2012).

\subsection{Thermal maturity of organic matter}

The type and maturity of organic matter in petroleum source rocks were characterized by Rock-Eval pyrolysis data. The maturation of the organic matter can be estimated by $T_{\max }$ range, $T_{\max } v s$. HI and numerical maturity calculation method. According to Espitalie (1986), for type

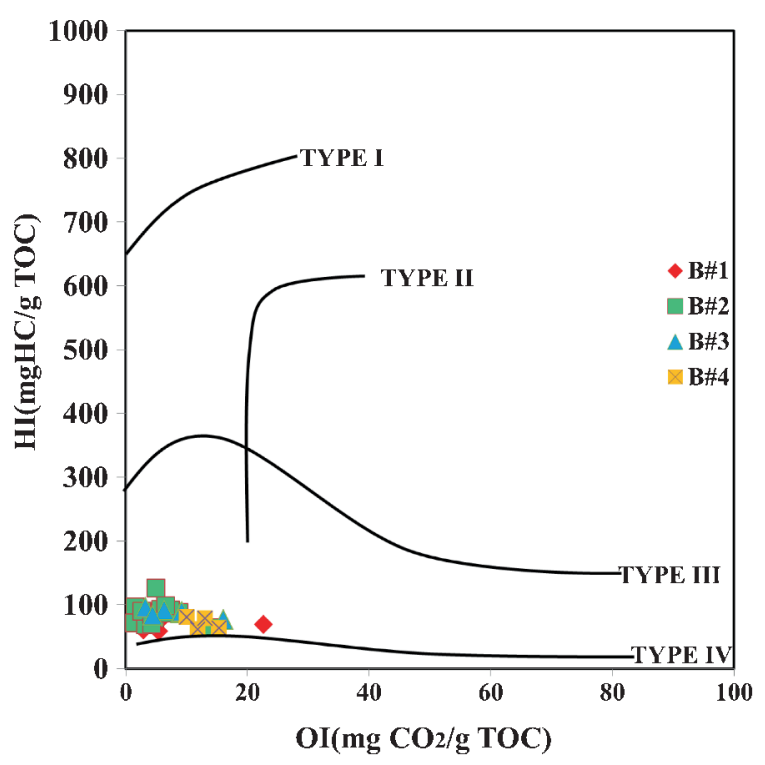

Figure 4. Modified Van Krevelen diagram indicating the kerogen type for Barren Measures shale. 


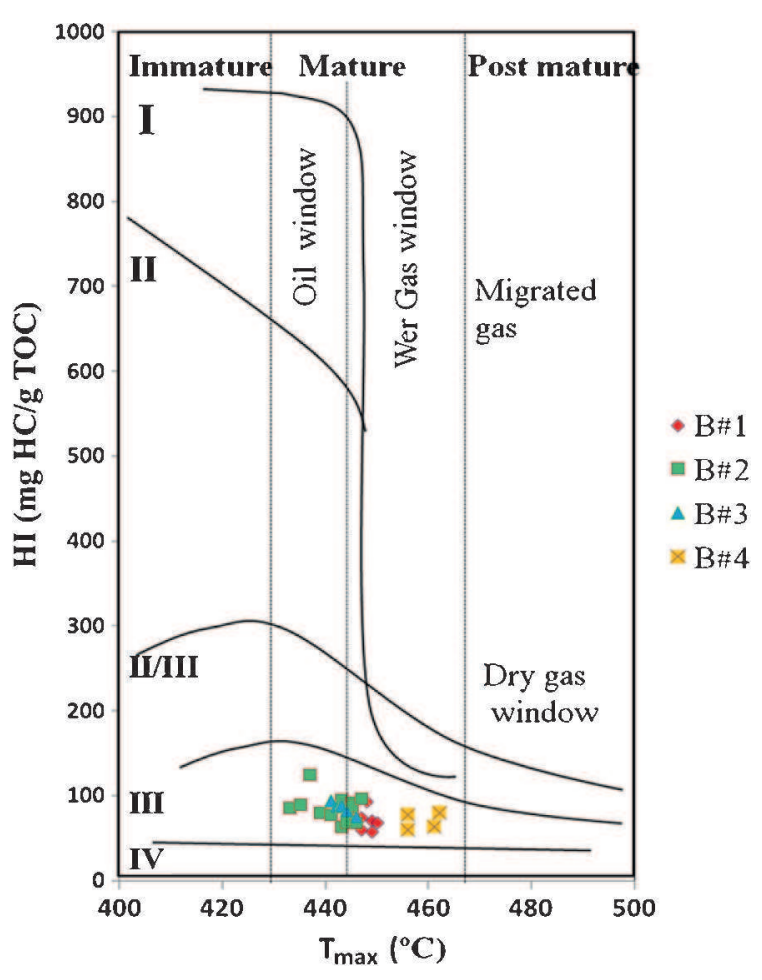

Figure 5. HI vs. $T_{\max }$ cross-plot. The plot shows the kerogen type and maturity range of the samples (after Espitalie et al. 1986).

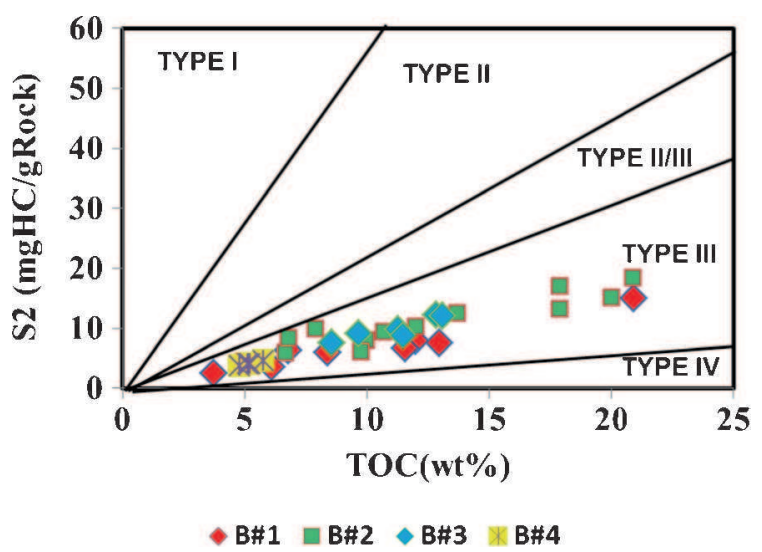

Figure 6. Cross plot of remaining hydrocarbon potential (S2) and TOC (wt\%) for Barren Measures shales. All the samples are falling in type III zone.

III organic matter, a $T_{\max }$ of $434^{\circ} \mathrm{C}$ is the boundary between immature and mature kerogen (oil production zone) whereas a $T_{\max }$ of $465^{\circ} \mathrm{C}$ is the boundary between mature and overmature kerogen (gas-production zone). The highest $T_{\max }$ value during pyrolysis analysis of organic material was recorded for samples from $\mathrm{B} \# 4$ at a depth of 350-355 m. Analysis of all the crucial Rock-Eval parameters (HI, OI and $T_{\max }$ ) refers early to late maturity level of the shales. Vitrinite reflectance is an optical method for measuring the source rock maturity (Tissot and Welte 1984). Vitrinite

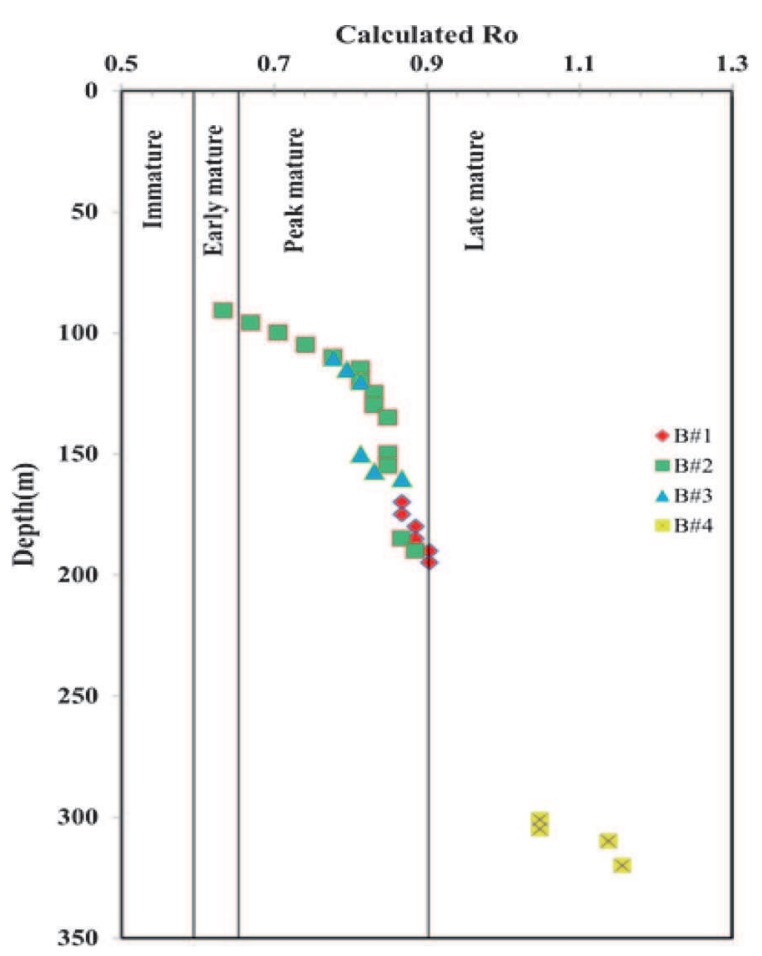

Figure 7. Depth vs. calculated maturity values of Barren Measures. The samples of borehole B\#4 are showing maximum maturity values (modified after Peters and Cassa 1994).

includes material derived from vascular plants (Hunt John 1995). With increasing maturity of organic matter, the reflectance (Ro) of light also increases. Since $T_{\max }$ obtained from Rock-Eval pyrolysis indicates the level of thermal maturity, it is possible to convert $T_{\max }$ to Ro (Dembicki 2009). The conversion can be mathematically expressed as Ro $($ calculated $)=(0.018)\left(T_{\max }\right)-7.16$ (Jarvie et al. 2001, 2007). The samples are showing the maturity range of $0.6-1.0 \%$ (figure 7 ). The crossplot of $\mathrm{S} 1$ vs. TOC\% was used to distinguish migrated hydrocarbons and contaminants from indigenous hydrocarbons (Hunt 1995). Figure 8 represents the plot of S1 vs. TOC for the analysed samples in this study. The findings suggest nonindigenous organic matter in Barren Measures. The highly matured sediments of catagenesis stage at shallow depth, where increasing maturity trend with respect to depth, implies geological control on both sediment deposition and thermal maturation. It also supports the presence of dry gas generation window of Barren Measures towards south-east part of the field at structurally depocentres. Postdepositional tectonic upliftment and subsequent thermal maturation indicates a south-eastward increasing trend of maturity level (Ghosh 2002; Varma et al. 2014). However, the tectonic history of the Raniganj Basin indicates deeper burial of the Barren Measures as compared to present day depth, which was rifted during Permian-Triassic (Ghosh 2002). 


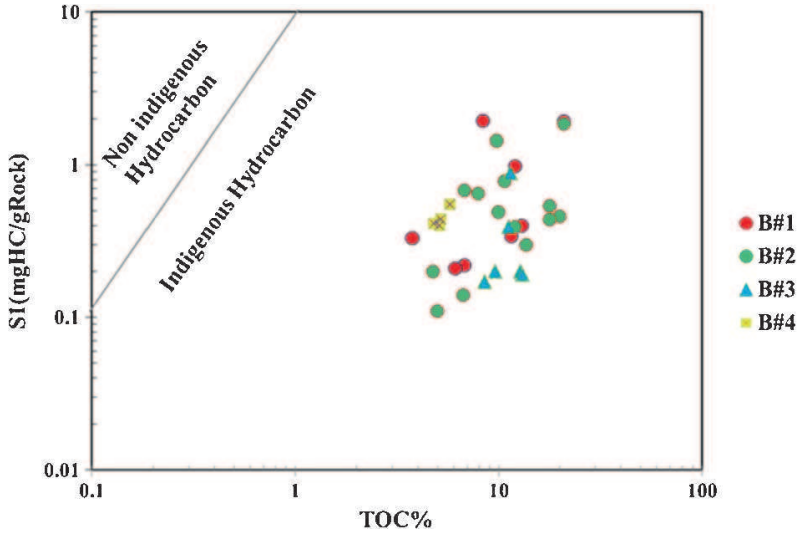

Figure 8. S1 vs. TOC (wt\%) cross plot shows all the samples are in the zone of indigenous hydrocarbon (after Hunt 1995).

The Barren Measures shale properties are identical to Antrim shale of Michigan Basin and also New Albany shale of Southern Indiana and Northern Kentucky (ONGC report 2010). The Antrim shale plays of Late Devonian age is almost $800-\mathrm{m}$ thick, TOC 1-25 wt\%, of both biogenic and thermogenic origin, Vro $0.4-0.6 \%$ and the shale is producing from the depth of 350-790 m (Roberts 1991). The New Albany shale is almost $30-50 \mathrm{~m}$ thick and producing from $160-600 \mathrm{~m}$ depth. The shale is of both thermogenic and biogenic origin with TOC $>3 \%$ and Vro $0.4-0.6 \%$ (Mastalerz 2013). Thus, the present analyses confirm the in situ gas generation competency of Barren Measures shale, even though it requires integrated geological, petrophysical, geo-mechanical investigations in finding sweet spots for shale gas exploration in the field.

\section{Conclusion}

Organic geochemistry and petrographic analyses suggest the Barren Measures shales are carbonaceous silty shale and iron rich claystone. TOC content ranges from 4 to $20 \mathrm{wt} \%$ and strongly reflect the vertical variation of TOC content due to conversion of organic matter to hydrocarbon in the subsurface. The shale samples analysed were thermally mature as indicated by Rock-Eval parameters and calculated vitrinite reflectance values, consist of mainly kerogen type III, deposited in anoxic condition and matured comparatively at shallower depth. The shale of Barren Measures has very good source rock generative potential and has obtained thermal maturity levels equivalent to the oil window. However, it has mainly gas generation potential as the organic matters are type III, derived from terrestrial matter. The thermal maturity of the shales is controlled by the burial history of the sediments. The Barren Measures may have excellent prospects for shale gas exploration if the exploration strategies are focussed considering the depth factor. In general, it may be concluded that the deepest and thickest shale sections of the sediments, will have the most favourable conditions for hydrocarbon generation prospectivity. Comparing the Barren Measures Rock-Eval data to some other analogue data of commercially gas producing shale plays has fetched confidence in the shale gas resource prognosis of the Raniganj field. Geochemical parameters along with petro-physical, reservoir, and geotechnical factors would be instrumental in precisely defining the sweet spots for shale gas exploration in Raniganj field.

\section{Acknowledgements}

The authors acknowledge the Coal Mine Planning and Designing Institute-RI-1 for providing samples for the study. Authors thank ED-HOD of Oil and Natural Gas Corporation Limited, Ahmedabad and Director of National Geophysical Research Institute, Hyderabad for providing permission to use laboratory facilities. Sincere thanks to Tarun Roy (HOD-CMPDI-I) and M Natarajan (Chief Geologist, IRS-ONGC) for their guidance and technical support. They also acknowledge Gujarat Energy Research and Management Institute, Gandhinagar for support and encouragement. The authors are also grateful to the anonymous reviewers who have helped to improve the quality of this manuscript.

\section{References}

Adams A E and Mackenzie W S 1998 A colour atlas of carbonate sediments and rocks under the microscope; Manson Publishing, London, pp. 6-9.

Adams A E et al. 1984 Atlas of sedimentary rock under microscope; Longman Group Ltd., England, pp. 15-36.

Akinlua A, Ajayi T R, Jarvie D M and Adeleke B B 2005 A reappraisal of the application of Rock-Eval pyrolysis to source rock studies in the Niger Delta; JPG 28 39-48.

Alias F L 2012 Organic geochemical characteristics and depositional environment of the Tertiary Tanjong Formation coals in the Pinangah area, onshore Sabah, Malaysia; Int. J. Coal Geol. 104 9-21.

Bacon C A, Calver C R, Boreham C J, Leaman D E, Morrison K C, Revill A T and Volkman J K 2000 The petroleum potential of onshore Tasmania - a review; Geol. Surv. Bull. 71 1-93.

Banerjee A et al. 1998 A mathematical representation of Rock-Eval hydrogen index vs. $T_{\max }$ profiles; Organic Geochem. 28(1) 43-55.

Banerjee S, Dutta S, Paikaray S and Mann U 2006 Stratigraphy, sedimentology and bulk organic geochemistry of black shales from the Proterozoic Vindhyan Super group (Central India); J. Earth Syst. Sci. 115(1) 37-47.

Barker C 1974 Pyrolysis techniques for source-rock evaluation; Am. Assoc. Petrol. Geol. Bull. 58(11) 2349-2361.

Bissada K K 1982 Geochemical constraints on petroleum generation and migration - a review; Proceeding from the Association of South East Asian Nations Council on Petroleum, Manila, Philippines 81 69-87. 
Boyer C and Rivera R S et al. 2006 Producing Gas from its Source; Oil Field Review, Autumn, pp. 36-49.

Bowker K A 2003 Recent developments of the Barnett shale play, Fort Worth Basin; West Texas Geol. Soc. Bull. 42 $4-11$.

Brown D 2006 Barnett may have Arkansas cousin; AAPG Explorer 27(2) 8-10.

Casshyap S M and Tewari R C 1988 Depositional models and tectonic evolution of Gondwana basins of peninsular India; The Palaeobotanist 36 59-66.

Chakraborty C, Ghosh S K and Chakraborty T 2003 Depositional record of tidal-flat sedimentation in the Permian coal measures of central India, Barakar Formation, Mohpani Coalfield, Satpura Gondwana Basin; Gondwana Res. 6(4) $817-827$.

CMPDIL 1993 Coal Atlas of India; 1st edn, Central Mine Planning and Design Institute Ltd., pp. 88-89.

Curtis J B 2002 Fractured shale-gas systems; Am. Assoc. Petrol. Geol. Bull. 85(11) 1921-1938.

Das R N 1992 Final report on regional exploration for coal in Chalbalpur-Mahismura Sector, Raniganj Coalfield, Barddhaman District, West Bengal; Geological Survey of India progress report, Field Seasons 1985-86 to 1989-90 7848.

Dasgupta P 2005 Facies pattern of the middle Permian Barren Measures Formation, Jharia basin, India: The sedimentary response to basin tectonics; J. Earth Syst. Sci. 114(3) 287-302.

Demaison G J and Moore G 1980 Anoxic environments and oil source bed genesis; Am. Assoc. Petrol. Geol. Bull. 64(8) 1179-1209.

Dembicki H 2009 Three common source rock evaluation errors made by geologists during prospect or play appraisals; Am. Assoc. Petrol. Geol. Bull. 93(3) 341-356.

Espitalie J 1986 Use of $T_{\max }$ as a maturation index for different types of organic matter, comparison with vitrinite reflectance; In: Thermal modelling in sedimentary basins, Burrus, J. Editions Technip, Paris, pp. 475-96.

Farhaduzzaman et al. 2012 Source rock potential of organicrich shales; In: The tertiary Bhuban and Boka Bil formations, Bengal Basin, Bangladesh; J. Petrol. Geol. 35(4) 357-376.

Fowler J W and Shirley J 1947 A method of making thin sections from friable materials and its use in the examination of shales from the coal measures; Geol. Mag. 84 354-359.

Fox C S 1931 The Gondwana system and related formation; Geol. Surv. India Memoir 57 1-241.

Ghosh S C 2002 The Raniganj Coal Basin: An example of an Indian Gondwana rift; Sedim. Geol. 147 155-176.

Greensmith J T 1988 Petrology of the Sedimentary Rocks; Unwin Hyman Ltd., Broadwick Street, London, pp. $165-180$.

Gupta A 1999 Early Permian palaeoenvironment in Damodar Valley coalfields, India: An overview; Gondwana Res. 2 149-165.

Herge M and Nordgard B et al. 2004 Origin of overpressure in shale: Constraints from basin modelling; Am. Assoc. Petrol. Geol. Bull. 88(2) 193-211.

Hunt John M 1995 Petroleum Geochemistry and Geology; 2nd edn, W.H. Freeman and Company, New York.

Jarvie D M and Lundell L L 1991 Hydrocarbon generation modelling of naturally and artificially matured Barnett Shale, Fort Worth Basin, Texas; Southwest Regional Geochemistry Meeting, Texas, Sept. 8-9.

Jarvie D M, Brenda L C, Floyd H and John T B 2001 Oil and shale gas from the Barnett Shale, Ft. Worth Basin, Texas; AAPG National Convention, June 3-6, 2001, Denver, CO; Am. Assoc. Petrol. Geol. Bull. 85(13).
Jarvie D M, Hill R J, Ruble $\mathrm{T}$ E and Pollastro R M 2007 Unconventional shale-gas systems: The Mississippian Barnett shale of north-central Texas as one model for thermogenic shale-gas assessment; Am. Assoc. Petrol. Geol. Bull. 91(4) 475-499.

Jarvie D M 2004 Assessment of the gas potential and yields from shales: The Barnett shale model; OGS-DOE Unconventional Energy Resources Conference, March 9-10, 2004.

Jenny H 1941 Factors of Soil Formation; McGraw-Hil, New York, USA.

Kennedy George C 1945 The preparation of polished thin sections; Econ. Geol. 40 353-360.

Kniesa J and Mannb U 2002 Depositional environment and source rock potential of Miocene strata from the central Fram Strait: Introduction of a new computing tool for simulating organic facies variations; Marine Petrol. Geol. $19811-828$.

Kuila U and Prasad M 2013 Specific surface area and pore size distribution in clays and shales; Geophysical Prospecting 61 341-362.

Lafargue E, Marquis F and Pillot D 1998 Rock-Eval 6 applications in hydrocarbon exploration, production, and soil contamination studies; Inst. Fr. P_et 53 421-437.

Law B E and Curtis J B 2002 Introduction to unconventional petroleum system; Am. Assoc. Petrol. Geol. Bull. 86(11) 1851-1852.

Leckie D A and Kalkreuth W D 1988 Source rock potential \& thermal maturity of lower Cretaceous strata, Monkman Pass area, British Colombia; Am. Assoc. Petrol. Geol. Bull. 72 820-838.

LNG World News 2011 ONGC finds shale gas near Durgapur; February 4. http://www.lngworldnews.com/ india-ongc-finds-shale-gas-near-durgapur.

Loucks R G, Reed R M, Ruppel S C and Jarvie D M 2009 Morphology, genesis, and distribution of nanometre-scale pore in siliceous mudstones of the Mississippian Barnett shale; J. Sedim. Res. 79 848-861.

Mani D, Patil D J, Dayal A M, Kavitha S, Hafiz M, Hakoo N and Bhat G M 2014 Gas potential of Proterozoic and Phanerozoic shales from the NW Himalaya, India: Inferences from pyrolysis; Int. J. Coal Geol. 128-129 81-95.

Mastalerz Maria 2013 Porosity of Devonian and Mississippian New Albany Shale across a maturation gradient: Insights from organic petrology, gas adsorption, and mercury intrusion; Am. Assoc. Petrol. Geol. Bull. 97 1621-1643.

Mishra R 2009 Cambay Shale: The Potential Barnett of India; ONGC Bull. 61-68.

Montgomery et al. 2005 Mississippian Barnett Shale, Fort Worth Basin, north-central Texas: Gas-shale play with multi-trillion cubic foot potential; Am. Assoc. Petrol. Geol. Bull. 89(2) 155-175.

Murthy S, Chakraborty B and Roy M D 2010 Palynodating of subsurface sediments, Raniganj Coalfield, Damodar Basin, West Bengal; J. Earth Syst. Sci. 119(5) 701-710.

Nuñez-Betelu L and Baceta J 1994 Basics and application of Rock-Eval/TOC pyrolysis: An example from the uppermost Palaeocene/lowermost Eocene in the Basque Basin, Western Pyrenees; MUNIBE (Ciencias Naturales - Natur Zientziak) San Sebastian 46 43-62.

ONGC 2010 Review and analysis of the Barren Measure shale in the North Karanpura \& Raniganj basins; Recommendation for exploration, well locations, definition of coring intervals, logging and data acquisition, ONGC Damodar Valley Shale Gas Pilot Project, No. ONGC/KDMIPE/Tech/Shale Pilot/2010-1(ONGC internal report). 
Parry W T, Jasumback M and Wilson P N 2002 Clay mineralogy of phyllic and intermediate argillic alteration at Bingham, Utah; Econ. Geol. 97 221-239.

Peters K E 1986 Guidelines for evaluating petroleum source rock using programmed pyrolysis; Am. Assoc. Petrol. Geol. Bull. 70(3) 318-329.

Peters K E and Moldowan J M 1993 The biomarker guide interpreting molecular fossils in petroleum and ancient sediments, Englewood Cliffs, New Jersey; Prentice Hall Inc., pp. 55-67.

Peters K E and Cassa M R 1994 Applied source rock geochemistry; In: The petroleum system - from source to trap (eds) Magoon L B and Dow W G, AAPG Memoir 60 93-120.

Pettijohn F J 1984 Sedimentary Rocks; 3rd edn, Harper and Raw Publisher, USA.

Potter P E, Mayand J and Pryor W A 1980 Sedimentology of shale; Springer Verlag, New York, Heidelberg, Berlin.

Roberts P A 1991 Antrim shale drilling and production statistics; Gas Research Institute; Devonian Gas Shales Technology Review 7(2) 50-55.

Ross and Bustin 2007 Shale gas potential of the Lower Jurassic Gordondale Member, northeastern British Columbia, Canada; Bull. Canad. Petrol. Geol. 55(1) 51-75.

Schlesinger W H 1977 Carbon balance in terrestrial detritus; Ann. Rev. Ecol. Syst. 8 51-81.

Schieber J 1996 Early diagenetic silica deposition in algal cysts and spores: Source of sand in black shales? J. Sedim. Res. 66 175-183.

Schieber J and Baird G 2001 On the origin and significance of pyrite spheres in Devonian black shales of North America; J. Sedim. Res. 71 155-166.
Slatt R M and Rodriguez N D 2012 Comparative sequence stratigraphy and organic geochemistry of gas shales: Commonality or coincidence; J. Nat. Gas Sci. Eng. 8 $68-84$.

Stein 2007 Upper Cretaceous/lower Tertiary black shales near the North Pole: Organic-carbon origin and sourcerock potential; Marine Petrol. Geol. 24 67-73.

Tissot B P and Welte D H 1984 Petroleum Formation and occurrence: A new approach to oil and gas exploration; 2nd edn, Springer Verlag, Berlin, pp. 150-169.

Tissot B P 1984 Recent advances in petroleum geochemistry applied to hydrocarbon exploration; Am. Assoc. Petrol. Geol. Bull. 68(5) 545-563.

Thiessen et al. 1938 Preparation of thin sections of coal; US Bur. Mines Information Circ. 7021 1-18.

Van Krevelen D W 1961 Coal: Typology-ChemistryPhysics-Constitution; Elsevier Science, Amsterdam, 514p.

Varma A K, Hazra B and Srivastava A 2014 Estimation of total organic carbon in shales through color manifestations; J. Nat. Gas Sci. Eng. 18 53-57.

Varma A K et al. 2015 Assessment of organic richness and hydrocarbon generation potential of Raniganj basin shales, West Bengal, India; Marine Petrol. Geol. 59 480-490.

Veevers J J and Tewari R C 1995 Gondwana master basin of peninsular India - between Tethys and the interior of the Gondwanaland-Province of Pangea; Geol. Soc. Am. Memoir 187 1-73.

Wang Guochang 2013 Organic-rich Marcellus shale lithofacies modeling and distribution pattern analysis in the Appalachian Basin; Am. Assoc. Petrol. Geol. Bull. 97(12) 2173-2205. 